\title{
Studi Deskriptif Motivasi Berprestasi Siswa MA Al-Fatah Palembang
}

\author{
Muhammad Irsyam Firnando ${ }^{a^{*}}$, Zuhdiyah $^{\text {b }}$, Eko Oktapiya Hadinata ${ }^{\text {c }}$ \\ ${ }_{a, b, c}$ Universitas Islam Negeri Raden Fatah Palembang \\ *Corresponding author : irsyamfirnando@gmail.com
}

\begin{abstract}
Abstrak
Penelitian ini bertujuan untuk mengetahui gambaran motivasi berprestasi siswa Madrasah Aliyah Al-Fatah Palembang. Penelitian ini menggunakan pendekatan studi kasus kualitatif. Penelitian ini bertujuan untuk memahami dan mendeskripsikan motivasi berprestasi siswa MA Al-Fatah Palembang. Teknik pengumpulan data data yang dingunakan adalah wawancara, observasi, dan dokumentasi. Informan berjumlah 3 orang, berjenis kelamin laki- laki,berusia 16 tahun. Pada penelitian ini, motivasi berprestasi yang dimiliki karena adanya rasa tanggung jawab, kreatif, inovatif. Adapun faktor orang tua, nilai raport,prestasi dibidang akademik dan non akademik
\end{abstract}

\section{Kata Kunci}

Motivasi; Prestasi; Tanggung Jawab

\begin{abstract}
This research was aimed to describe the achievement motivation of students in Madrasah Aliyah Al-Fatah Palembang. This study aims to understand and describe the achievement motivation of MA Al-Fatah Palembang students. Data collection techniques used are interviews, observation, and documentation. There were 3 informants, male, 16 years old. In this study, achievement motivation possessed because of a sense of responsibility, creative, innovative. The factors of parents, report cards, academic and non-academic achievements
\end{abstract}

\section{Keywords}

Motivation; Achievement; Responsibility 


\section{Pendahuluan}

$\mathrm{P}$ endidikan merupakan proses pembentukan kecakapan, baik secara intelektual maupun emosional serta pengembangan potensi untuk dapat menghasilkan sumberdaya manusia yang berkualitas. Menurut undang-undang nomor 20 tahun 2003 tentang sistem Pendidikan Nasional, pendidikan dibagi menjadi 3 tahapan yaitu, jalur nonformal (luar sekolah), informal (pendidikan dalam keluarga), formal (persekolahan) dalam penggalian minat dan bakat. Sekolah Menengah Atas (SMA) atau Madrasah Aliyah (MA) adalah jenjang pendidikan formal setelah sekolah menengah atas (SMP) dalam tahapannya sekolah menengah atas ini berjalan sepanjang 3 tahun dimana siswa memulai sekolah dari kelas $\mathrm{X}$ hingga kelas XII. Pembelajaran di SMA/MA mempersiapkan siswa untuk melanjutkan studinya ke jenjang pendidikan yang lebih tinggi, oleh karenanya terdapat penjurusan di SMA/MA, penjurusan diharapkan dapat lebih mengarahkan siswa memilih bidang ilmu/program studi di perguruan tinggi yang nantinya akan mengarah pada kariernya kelak.

Kurikulum madrasah aliyah sama dengan kurikulum sekolah menengah atas, hanya saja pada MA terdapat porsi lebih banyak muatan pendidikan agama Islam, yaitu Fiqih, akidah, akhlak, Al Quran, Hadits, Bahasa Arab dan Sejarah Kebudayaan Islam. Pelajar madrasah aliyah umumnya berusia 16-18 tahun. SMA/MA tidak termasuk program wajib belajar pemerintah, sebagaimana siswa sekolah dasar/sederajat 6 tahun dan sekolah menengah pertama/sederajat 3 tahun. Di
Indonesia, kepemilikan madrasah aliyah dipegang oleh dua badan, yakni swasta dan pemerintah (madrasah aliyah negeri).

Salah satu keberhasilan siswa dalam pendidikan ditunjukkan dengan prestasi akademiknya dan non akademik. Pada kenyataannya ditemukan tuntutan prestasi akademik pada siswa semakin tinggi sementara daya belajarnya biasa- biasa saja. Hal inilah yang menyebabkan tingkat keberhasilan siswa dalam prestasi akademik kurang sebagaimana diharapkan oleh sekolah, orang tua dan siswa itu sendiri. Fungsi pendidikan salah satunya adalah membentuk sikap dan orientasi siswa terhadap belajar, menanamkan sikap positif dan haus akan pengetahuan serta untuk mengembangkan keterampilan belajar secara efektif. Keberhasilan siswa dalam pendidikannya juga dipengaruhi oleh motivasi berprestasi yang dimiliki. Motivasi berprestasi sebagai daya dorong yang memungkinkan seseorang berhasil mencapai apa yang diidamkan.

Seseorang yang memiliki motivasi berprestasi tinggi cenderung untuk selalu berusaha mencapai apa yang diinginkan walaupun mengalami hambatan dan kesulitan dalam meraihnya. Pada kenyataannya motivasi berprestasi yang dimiliki oleh seseorang cenderung sering mengalami penurunan dan di waktu lain mengalami peningkatan. Motivasi berprestasi yang dimiliki seseorang idealnya selalu mengalami progresif atau kemajuan sehingga akan mempercepat apa yang diidamkan. Hal inilah yang belum dimiliki oleh generasi muda untuk selalu meningkat motivasi berprestasinya. Siswa MA sebagai bagian dari generasi muda, dipersiapkan agar dapat melanjutkan pendidikan ke jenjang yang lebih tinggi 
serta menekuni bidang keahliannya. Belum semua siswa mempunyai motivasi berprestasi yang tinggi dalam mengikuti pelajaran sehingga prestasi akademik yang dicapai masih banyak dalam klasifikasi minimal lulus jika dilihat dari kemampuan siswa mampu mencapai prestasi akademik yang lebih tinggi, sehingga dapat diharapkan dengan peningkatan motivasi berprestasi dapat menunjang pencapaian prestasi akademik dan non akademik yang diraih siswa. Prestasi diperoleh dari usaha yang telah dikerjakan. Dari pengertian prestasi tersebut, maka pengertian prestasi diri adalah hasil atas usaha yang dilakukan seseorang.

Prestasi dapat dicapai dengan mengandalkan kemampuan intelektual, emosional, dan spiritual, serta ketahanan diri dalam menghadapi situasi segala aspek kehidupan. Karakter orang yang berprestasi adalah mencintai pekerjaan, memiliki inisiatif dan kreatif, pantang menyerah, serta menjalankan tugas dengan sungguhsungguh Karakter- karakter tersebut menunjukan bahwa untuk meraih prestasi tertentu, dibutuhkan kerja keras. Prestasi adalah sebagai rumus yang diberikan guru mata pelajaran mengenai kemajuan atau prestasi belajar selama periode tertentu. (Sumadi Suryabrata, 1998).

Sedangkan menurut Mc Clelland (1961) bahwa individu akan mengerjakan sesuatu dengan gigih dan risiko pekerjaannya moderat, maka dia akan bekerja lebih tanggung jawab dan memperoleh umpan balik atas hasil prestasinya. Motivasi berprestasi ini mengarah terhadap kepentingan masa depan dibandingkan masa lalu atau masa kini dan individu akan menjadi lebih kuat dalam menghadapi kegagalan, karena dirinya dapat memperkirakan situasi yang akan datang untuk memperoleh prestasi yang lebih baik dalam bekerja. Siswa akan terdorong untuk belajar manakala mereka memiliki motivasi untuk belajar. 1) Kuatnya kemauan untuk berbuat, 2) Jumlah waktu yang disediakan untuk belajar, 3) Kerelaan meninggalkan kewajiban atau tugas yang lain, 4) Ketekunan dalam mengerjakan tugas. Suprihatin (2015). Karateristik motivasi berprestasi menurut Mc Clelland (1998) yaitu :

a) Adanya tanggung jawab

b) Mempertimbangkan resiko

c) Kreatif dan Inovatif

d) Membutuhkan umpan balik.

Dari pendapat ahli di atas dan merujuk pada fenomena di lapangan bahwa orang yang mepunyai motivasi berprestasi adalah orang yang mempunyai tanggung jawab, mempertimbangkan resiko, kreatif dan inovatif dan membutuhkan umpan balik. Peneliti telah melakukan wawancara pada seorang siswa yang berinisial BB umur 16 tahun pada tanggal 2 oktober 2018, saat di wawancarai subjek terlihat sedikit diam ketika pertama kali bertemu dan menjawab pertanyaan dari peneliti. Ia mengungkapkan bahwa ia sudah berestasi dari kelas X. "tiap malam aku belajar dan buat pr dewekan di kamar kak sampe jam 10 malem, ketika di dalem kelas aku memperhatike dan ku catet apo yang di jelaske oleh guru di sekolah, banyak kawan yang ngajak ngobrol ketika pelajaran mulai kak tapi aku diemke bae dan aku fokus perhatike apo yang guru jelaske di papan tulis, aku mulai ranking 1 dari kelas $X$, aku jarang keluar ketika jam istirahat sekolah banyak lah aku baco buku di dalem kelas, aku bawak bekal dewek kak dari rumah dan aku jugo pernah ikut Tahfiz 
Al-Qur'an tingkat nasional kak" (2 oktober 2018). Selanjutnya peneliti mewawancarai guru berinisial D umur 36 tahun ia menjelaskan memang benar subjek BB adalah murid yang rajin dan berprestasi di MA Al- Fatah (wawancara pada tanggal 5 Oktober) .Dari fenomena dan uraian di atas, penelitian ini bertujuan untuk mengeksplorasi gambaran motivasi berprestasi siswa MA AL FATAH Palembang.

\section{Metode}

Pada penelitian ini, jenis penelitian yang dilakukan yaitu penelitian kualitatif deskriptif. Penelitian kualitatif adalah penelitian yang memiliki tahapan yang melampaui berbagai tahapan berpikir kritisilmiah di mana seorang peneliti memulai berpikir secara induktif yaitu menangkap berbagai fakta atau fenomena-fenomena sosial melalui pengamatan di lapangan, dan kemudian berupaya melakukan teorisasi berdasarkan apa yang di amati itu. Peneliti di arahkan oleh produk berpikir induktif untuk menemukan jawaban logis terhadap apa yang sedang menjadi pusat perhatian dalam penelitian, dan akhirnya produk berpikir induktif menjadi jawaban sementara terhadap apa yang dipertanyakan dalam penelitian dan menjadi perhatian itu, jawaban tersebut dinamakan dengan berpikir induktifanalitis (Bungin, 2008).

\section{Hasil}

Penelitian ini membahas tentang motivasi berprestasi pada siswa yang mana motivasi sangat penting dimiliki oleh setiap individu karna dengan motivasi yang besar akan sangat senang kalau ia berhasil memenangkan suatu persaingan. Subjek memmiliki motivasi yang tinggi dan memiliki berbagai macam motivasi akan tetapi kebanyakan dari subjek memiliki motivasi karna mereka ingin membahagiakan kedua orang tua mereka dengan demikian subjek sangat giat belajar, mengerjakan tugas dan berlatih, karna motivasi sangat berpengaruh bagi prestasi subjek hal ini seperti yang di kemukakan Hal tersebut senada dengan apa yang di ungkapkan oleh ahli Motivasi adalah kebutuhan manusia tersusun dari suatu hierarki. Tingkat kebutuhan yang paling rendah adalah kebutuhan fisiologis dan yang paling tinggi adalah kebutuhan aktualisasi diri. Robbins dan Judge (2008) digambarkan dalam suatu hierarki lima kebutuhan dasar manusia menurut Abraham H. Maslow, yaitu:

1. Kebutuhan fisiologis (Physiologocal needs), meliputi rasa lapar, haus, berlindung, seksual dan kebutuhan fisik lainnya.

2. Kebutuhan keamanan dan keselamatan kerja (Security or safety needs), meliputi rasa ingin dilindungi dari bahaya fisik dan emosional.

3. Kebutuhan sosial (Affiliation or acceptance needs), meliputi rasa kasih sayang, kepemilikan, penerimaan dan persahabatan.

4. Kebutuhan penghargaan (Esteem needs), meliputi penghargaan internal seperti hormat diri, otonomi dan pencapaiannya serta faktor-faktor penghargaan eksternal seperti status pengakuan dan perhatian.

5. Kebutuhan aktualisasi diri (Needs for self actualization), dorongan untuk menjadi seseorang sesuai kecakapannya meliputi pertumbuhan, pencapaian potensi seseorang dan pemenuhan diri sendiri. 
Dari pendapat para ahli tersebut dapat di benarkan bahwa semakin tinggi motivasi yang di miliki individu maka semakin tinggi pula kesuksesannya atau prestasinya hal ini dapat di lihat dari semua subjek penelitian yang kesemuanya memiliki motivasi yang sangat tinggi terutama mereka ingin melihat orang yang mereka sayangi dan orang yang telah bersusah payah menyekolakan mereka bahagia dengan demikian dorongan subjek tersebut membuat mereka semangat dan giat untuk belajar sehingga membuat mereka meraih prestasi dalam bidang akademik maupun non akademik. Subjek merupakan remaja yang ber inisial BB (16) RR (16) AF (15) yang mana kehidupan subjek sama seperti siswa pada umumnya belajar dan bermain, dan membantu kedua orang tuanya. sebagaimana yang di ungkapkan Mappiare masa remaja berlangsung antara umur 12 tahun sampai dengan 21 tahun bagi wanita dan 13 tahun sampai dengan 22 tahun bagi pria. rentan usia tersebut di bagi menjadi dua bagian yaitu usia 12/13 tahun sampai dengan 17/18 tahun adalah remaja awal dan usia 17/18 tahun sampaii usia 21/22 tahun adalah remaja akhir (Ali,2011). Subjek adalah orang yang menganggap tugastugas yang di berikan guru adalah sebuah tanggung jawab sehingga subjek selalu mengerjakan tugas yang di berikan di berikan guru Mereka akan berusaha untuk menyelesaikannya dan tidak akan meninggalakan tugas tersebut walau semakin sulit sebelum mereka menyelesaikannya (McClelland, 1961).

Hal ini dikarenakan individu akan merasa berhasil jika telah menyelesaikan tugas dan gagal bila mereka tidak berhasil menyelesaikan tugas. Dari uraian di atamengemban tanggung jawab. Dilihat dari latar belakang keluarga kesemua subjek masih memiliki orang tua yang utuh, pekerjaan orang tua subjek berbeda-beda ada bekerja sebagai pedagang. Ada juga yang bekerja sebagai swasta. Kehidupan subjek dengan keluarganya pun baik dan sangat akrab. sehingga Hal ini setidaknya bisa menjadi rujukan bahwa bahwa orangtua menjadi salah satu pendukung motivasi yang di miliki subjek Subjek bukan orang yang kehilangan kasih sayang, perhatian dan tanggung jawab dari orang tuanya. Hal ini diperkuat oleh pernyataan subjek yang mengatakan bahwa hubungan mereka dengan keluarganya sangat baik dan terjalin kedekatan antara anak dan orang tuanya hal ini karna adanya parental control bagaimana orang tua mengontrol, membimbing, dan mendampingi anakanaknya untuk melaksanakan tugas perkembangannya menuju pada proses pendewasaan (Muallifah,2009). Sedangkan menurut Hetherington dan Porke (1999) dikutip oleh Sanjiwani, pola asuh merupakan bagaimana cara orang tua berinteraksi dengan anak secara total yang meliputi proses pemeliharaan, perlindungan dan pengajaran bagi anak (Sanjiwani,2014). Sejalan dengan hal itu Hersey dan Blanchard (1978) dikutip Garliah, pola asuh adalah bentuk dari kepemimpinan. Pengertian kepemimpinan itu sendiri adalah bagaimana mempengaruhi seseorang, dalam hal ini orang tua berperan sebagai pengaruh yang kuat pada anaknya (Garliah,2005). Muallifah lebih menekankan kepada bagaimana kualitas pola asuh orang tua yang baik yaitu orang tua yang mampu memonitor segala aktivitas anak, walaupun kondisi anak dalam keadaan baik atau tidak baik, orang tua harus memberikan dukungannya (Muallifah, 2009). Ia berani menanggung segala resiko sebagai konsekwensi dari usahanya untuk mencapai 
tujuan karena dengan motivasi daya penggerak di dalam diri seseorang untuk berbuat sendiri.

Motivasi juga merupakan kondisi internal individu yang mendorongnya untuk berbuat sesuatu. Peran motivasi adalah sebagai pemasok daya (energizer) untuk tingkah laku secara terarah dengan semakin tingginya motivasi akan medorong idividu unutuk menjadi orang yang baik contoh nya anak sekolah ingin memiliki prestasi karna hal tersebut idaman setiap individu, baik itu prestasi dalam bidang pekerjaan, pendidikan, sosial, seni, politik, budaya dan lain-lain. Dengan adanya prestasi yang pernah diraih oleh seseorang akan menumbuhkan suatu semangat baru untuk menjalani aktifitas. Korban dapat di simpulkan dari pembahasan diatas bahwa subjek kesemuanya merupakan remaja, yang memiliki motivasi yang sangat tinggi untuk mengai apa yang di inginkan, orangtua yang bertanggungn jawan menjadi salah satu motivasi bagi subjek untuk giat belajar dan mengerjakan tugas karna bagi subjek hal tersebut merupakan tanggung jawab yang harus ia lakukan.

\section{Kesimpulan}

Berdasarkan hasil penelitian dapat disimpulkan bahwa subjek kesemuanya merupakan remaja, yang memiliki motivasi yang tinggi untuk menggapai apa yang diinginkan, orangtua yang bertanggungn jawan menjadi salah satu motivasi bagi subjek untuk giat belajar dan mengerjakan tugas karna bagi subjek hal tersebut merupakan tanggung jawab yang harus ia lakukan.subjek merupakan siswa yang berprestasi baik itu di bidang akademik maupun non akademik, subjek tergabung dalam grub Hadroh yang perna menjuarai berbagai jenis perlombaan yang pernah mereka ikuti selain itu subjek juga memiliki prestasi yang baik di dalam kelasnya. Adapun faktor yang mempengaruhi subjek menjadi pemicu motivasi berproses belajarnya, nilai raport, prestasi non akademik, ingin menjadi orang yang di banggakan oleh orang tuanya sehingga subjek tekun dalam menjalani proses belajar.

\section{Daftar Pustaka}

Bungin, B. (2012). Penelitian Kualitatif Edisi Kedua. Jakarta: Kencana

Herdiansyah, H. (2014). Metode Penelitian Kualitatif Untuk Ilmu- Ilmu Sosial, Jakarta: Selatan, Salemba Humanika

Herdiansyah, H. (2015). Metode Penelitian Kualitatif Untuk Ilmu Psikolagi, Jakarta: Salemba Humanika

Jack. C. Richards. (1999). Longman Dictionary of Language Teaching and Appied Linguistics, Malaysia: Longman Group

Lili Garliah dkk. (2005). Peran Pola Asuh Orang Tua dalam Memotivasi Berprestasi. Jurnal psikologi, Vol. 1, No. 1, Juni.

Maslow, A., H. (2010). Motivation And Personality, Jakarta: Rajawali

Mc.Clelland, D. (1992). Menjamu Masyarakat Berprestasi, Jakarta: Cv.Intermedia.

Mc.Clelland, D. (1992). The Achivement Motive, New York: Appleton Century Craft.

MoleongLexy J. (2014). Metodologi Penelitian Kualitatif .bandung: PT Remaja Rosda karya.

Muallifah. (2009). Psycho Islamic Smart Parenting, DIVA Press (Anggota IKAPI),

Sudjana, N. (1989). Penelitian dan Penilaian Pendidikan, Bandung: Sinar Baru

Nasution. (1988). Methodologi Penelitian Naturalistik, Bandung: PN. Tarsit 
Poerwandari. K., E. (2007). Pendekatan Kualitatif Untuk Penelitian Prilaku Manusia, Depok, LPSP3 UI.

Singarimbun, M. (1989). Metodologi Penelitian Survey, Cet I, Jakarta: P3ES.

Sugiyono. (2013). Metode Penelitian Kuantitatif Kualitatif Dan RND. Bandung: Alfabeta.

Suryabrata, S. (2002). Psikologi pendidikan. Jakarta : Raja Grafindo Persada.

Winkel, W., S. (1983). Psikologi pengajaran. Jakarta: PT Gramedia Widiasarana Indonesia. 